\title{
Citizen Science Helps in Tracking the Range Expansions of Non-Indigenous and Neo-Native Species in Greece and Cyprus (Eastern Mediterranean Sea)
}

\author{
Joachim Langeneck ${ }^{1}$, Vasileios Minasidis ${ }^{2,3}{ }^{(0)}$, Nikolaos Doumpas ${ }^{3}$, Ioannis Giovos ${ }^{2,3,4}$, Alexandros Kaminas ${ }^{3}$,

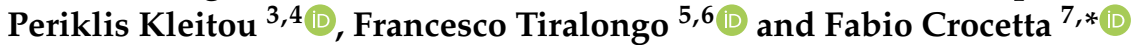

check for updates

Citation: Langeneck, J.; Minasidis, V.; Doumpas, N.; Giovos, I.; Kaminas, A.; Kleitou, P.; Tiralongo, F.; Crocetta, F. Citizen Science Helps in Tracking the Range Expansions of Non-Indigenous and Neo-Native Species in Greece and Cyprus (Eastern Mediterranean Sea). J. Mar Sci. Eng. 2022, 10, 256. https:// doi.org/10.3390/jmse10020256

Academic Editors: Dan Tchernov, Caterina Longo and Dariusz Kucharczyk

Received: 16 December 2021 Accepted: 11 February 2022 Published: 14 February 2022

Publisher's Note: MDPI stays neutral with regard to jurisdictional claims in published maps and institutional affiliations.

Copyright: (C) 2022 by the authors. Licensee MDPI, Basel, Switzerland. This article is an open access article distributed under the terms and conditions of the Creative Commons Attribution (CC BY) license (https:// creativecommons.org/licenses/by/ $4.0 /)$.
1 Dipartimento di Biologia, Università di Pisa, via Derna 1, I-56126 Pisa, Italy; jlangeneck@biologia.unipi.it

2 Department of Animal Production, Fisheries and Aquaculture, University of Patras, 30200 Mesolongi, Greece; vasileios.minasidis@upatras.gr (V.M.); ioannis.giovos@isea.com.gr (I.G.)

3 iSea, Environmental Organisation for the Preservation of the Aquatic Ecosystems, 54645 Thessaloniki, Greece nikolaos.doumpas@isea.com.gr (N.D.); kaminas.alex@gmail.com (A.K.); pkleitou@merresearch.com (P.K.)

4 Marine \& Environmental Research (MER) Lab., 202 Amathountos Avenue, Marina Gardens, Block B, Limassol 4533, Cyprus

5 Department of Biological, Geological and Environmental Sciences, University of Catania, 95124 Catania, Italy; francesco.tiralongo@unict.it

6 Ente Fauna Marina Mediterranea, Scientific Organization for Research and Conservation of Marine Biodiversity, 96012 Avola, Italy

7 Department of Integrative Marine Ecology, Stazione Zoologica Anton Dohrn, Villa Comunale 1, 80121 Naples, Italy

* Correspondence: fabio.crocetta@szn.it; Tel.: +39-081-583-3217

\begin{abstract}
Raising knowledge of the dispersal of non-indigenous species (NIS) in new geographic areas is a matter of major concern, as alien species may outcompete the native biota through competition, predation, and hybridization. In the Mediterranean Sea, where biological invasions constitute a serious threat, the combined use of citizen science and social networks amplified the results obtained via traditional research activities, often recording species that would otherwise presumably have passed unnoticed. We hereby report unpublished data for five NIS (the annelid Branchiomma luctuosum, the shrimp Saron marmoratus and the fishes Lutjanus argentimaculatus, Oxyurichthys petersii, and specimens of the group of Abudefduf saxatilis/vaigiensis/troschelii) and one neo-native species (Seriola fasciata) in Greece and Cyprus (eastern Mediterranean Sea), the majority of which were obtained via a focused citizen-science project and constitute new records at a country level. We also revise and update their known distribution in the invaded area, thus contributing to the study of largescale and well-defined distributional patterns of alien species spreading in the Mediterranean Sea.
\end{abstract}

Keywords: biological invasions; Lessepsian migration; non-indigenous species; alien spreading; distribution; coastal monitoring; social networks; Levantine Sea; Aegean Sea; Ionian Sea

\section{Introduction}

Non-indigenous species (NIS) represent one of the major threats to marine environments and can strongly affect ecosystem functioning, with additional potential effects on socioeconomic activities [1,2]. The close monitoring of new introductions and range expansions is crucial to correctly assess ecosystem changes and potential impacts on ecological and social systems [3-5]. Despite recent efforts to compile a database with a sizable number of occurrences of NIS in the Mediterranean Sea, the majority of the literature on NIS refers to the first records for a specific geographic area, while population and range expansions at a regional scale are often neglected and/or remain unpublished [6]. The species in this study, in particular, are also easily overlooked by traditional monitoring techniques [7] but, at the same time, might have a relevant impact on native assemblages in case of naturalization [8]. 
In this framework, citizen science arises as an important source of distributional data that allows researchers to track NIS and neo-native species expansion processes, and represents an early warning of possible biological invasions $[9,10]$. Citizen science data can subsequently be gathered and included in the scientific literature and may help in identifying new occurrences of potentially invasive species (e.g., [11,12]) or monitoring their densities and guiding management interventions [13,14].

The project "Is it Alien to you? Share it!!!" was designed and launched with the main aim of gathering data about NIS, cryptogenic, neo-native, and poorly known native species in Greece and other Eastern Mediterranean countries [15]. During the first three years of the project, it allowed researchers to update the distribution of several high-impact NIS that were hitherto considered mostly limited to the easternmost part of the Mediterranean Sea, among which are the cephalopod Sepioteuthis lessoniana d'Orbigny, 1826, the pufferfish Torquigener flavimaculosus Hardy and Randall, 1983, and the lionfish Pterois miles (Bennett, 1828) [15]; additional results were obtained in the following years, regarding both NIS and rare native species $[6,12,16-18]$.

We hereby contribute to the knowledge of new species spreading in the Mediterranean Sea by reporting new distributional data for five NIS and one neo-native species and updating the data concerning their distribution in the basin.

\section{Materials and Methods}

The project "Is it Alien to you? Share it!!!", designed and launched in 2016 by iSea (a Greek environmental organization), implemented the establishment of an online data repository on which citizen scientists can upload photographic material along with additional information, such as specimen size (length and/or weight), the depth at which the specimen was recorded, the number of specimens recorded (or approximate density in case of sessile taxa), exact location, date, type of observation (freediving, underwater photography, shore-base fishing, boat-based fishing, spearfishing), the substrate and the occupation and experience of the reporter (recreational fisher, photographer, naturalist, etc.). The online data repository is currently complemented by a Facebook group, where citizen scientists are able to share their pictures and obtain the opinion of an expert on taxonomic identification. All pictures are checked for their authenticity and originality using the automatic image recognition tool by Google; all pictures that are verified as authentic are sent to a team of taxonomic experts that identifies the species to the lowest taxonomic level possible and validates the observations, before uploading the record onto the project's database (see [15] for further details on the project). Although the iSea database contains a number of records for already established NIS, thus confirming their occurrence in the Eastern Mediterranean Sea, we here concentrated on records expanding the known distribution of species in new countries and/or new biogeographical sectors within the Mediterranean Sea. Taxonomic nomenclature and systematics have been equalized with WoRMS (https: / / www.marinespecies.org/, last accessed on the 5 January 2022).

\section{Results and Discussion}

We obtained distributional data for six species, five of which should be considered nonindigenous to the Mediterranean Sea, while a sixth one (Seriola fasciata) is a thermophilic (neo-native) Atlantic species naturally spreading into the Mediterranean. One species (Branchiomma luctuosum) constitutes a new record at a regional scale, whereas five species (Abudefduf cf. saxatilis/vaigiensis/troschelii, Lutjanus argentimaculatus, Oxyurichthys petersii, Saron marmoratus, Seriola fasciata) constitute new records at a country level. In addition, since georeferenced occurrences of $O$. petersii are still scanty, we chose to also include additional records for this species.

Phylum Annelida Lamarck, 1802

Class Polychaeta Grube, 1850

Order Sabellida Levinsen, 1883 
Family Sabellidae Latreille, 1825

Genus Branchiomma Kölliker, 1858

Branchiomma luctuosum (Grube, 1870)

(Figure 1A)

Material examined. Several specimens were recorded in a video format; 3 specimens were sampled and stored in 70\% alcohol at the iSea collection, and were collected from Messolonghi harbor, Greece, Ionian Sea (38.3631 N, 21.4212 E), on 20 October 2020. The specimens were found at $2 \mathrm{~m}$ depth, on docks encrusted with calcifying species, with an average density of about $4-5$ individuals $/ \mathrm{m}^{2}$, and were sampled by Vasileios Minasidis.

Remarks. Branchiomma luctuosum is a widespread non-indigenous habitat-forming polychaete showing variable invasion success in different Mediterranean areas. After the first record in Lake Lucrino in 1979 [19], this species was recorded in several locations along the Italian coastline, usually at high densities [20]. A similar invasion success, although significantly delayed, was reported on the Mediterranean Spanish coastline, where the species was first recorded in Valencia harbor [21] and is currently widespread in the southern part of the Iberian Peninsula, including some Atlantic harbors around Gibraltar [22]. In other Mediterranean areas, the species is still scantily reported, with only one record for the eastern Adriatic Sea [23], two records for the Aegean Sea [24,25], two for the Levantine Sea [26,27], and two for the southern Mediterranean Sea [28,29]. In Greece, only two reports are known, both for the Aegean Sea; thus, the record for Messolonghi harbor represents the first occurrence of this species in the Eastern Ionian Sea. However, the abundant population reported by Tanduo et al. [23] for Vlora Bay (Albania, southeastern Adriatic Sea) suggests that the species might be widespread in this geographical sector as well. The population of $B$. luctuosum from Messolonghi shows a relatively low density when compared with historical data from other Mediterranean areas [22]. In general, although B. luctuosum can occur locally in pristine environments [20,22], it manages to structure abundant populations only in enclosed environments, such as brackish-water coastal ponds [20,23] and ports $[22,30,31]$. The scarcity of detailed study from port assemblages in Greece [32] might possibly account for the alleged rarity of this species, and it is likely that further studies in Greek port environments will highlight a wider distribution of B. luctuosum. Although the first studies suggested a strong competitive effect of this species on the native Sabella spallanzanii (Gmelin, 1791), which seemed to be almost completely replaced by B. luctuosum [33], further studies highlighted a spatial and temporal variability of population dynamics in this species, suggesting that the impact of B. luctuosum might strongly depend on local environmental conditions. This species is an important habitat-former in Mediterranean ports, with the possibility of not only locally increasing biodiversity but also favoring the establishment and spread of other NIS [22]. The impact on pristine environments seems, instead, less pronounced, as individuals of B. luctuosum sampled outside port areas are distinctly smaller [22].

Phylum Arthropoda von Siebold, 1848

Class Malacostraca Latreille, 1802

Order Decapoda Latreille, 1802

Family Hippolytidae Spence Bate, 1888

Genus Saron Thallwitz, 1891

Saron marmoratus (Olivier, 1811)

(Figure 1B)

Material examined. One specimen was photographed by Stefanos Michael in Protaras, Cyprus, Levantine Sea (35.0007 N, 34.0683E), on 24 August 2021. The specimen was found at $2 \mathrm{~m}$ depth, on a hard-bottom, in association with the non-indigenous sea urchin Diadema setosum (Leske, 1778). 
Remarks. Although the specimen was not collected, its characteristic morphological features and its live color [34] allowed us to univocally assign it to S. marmoratus. This species is a relatively recent addition to the Mediterranean fauna, as it was first reported in Mediterranean Israeli waters [34], where the species appears to be now established [6], and was later recorded only off the coasts of Lebanon [35], Syria [36], and in Iskenderun Bay, Turkey, Levantine Sea [37]. The current record represents the first sighting for Cyprus, as well as evidencing a relevant range expansion westward. Although this is an ornamental species and it is widespread in the aquarium trade, its presence in the Red Sea and the colonization dynamics observed, typical for Lessepsian species, strongly suggest an arrival via the Suez Canal, possibly in its planktonic larval stages [34]. As this species is currently known only from a handful of records, and it seems to be at the early stages of its colonization, there is no reliable data allowing researchers to infer its possible impacts on native species and assemblages.



Figure 1. NIS and neo-native species newly recorded from Greece and Cyprus (part 1). New distributional data are marked by a black star. (A) Branchiomma luctuosum from Messolonghi harbor (Greece) and known records in the Mediterranean Sea and the adjacent Atlantic Ocean (after [22,28,29]. Frame from a video: Vasileios Minasidis. (B) Saron marmoratus from Protaras (Cyprus) and known records in the Mediterranean Sea (after [6,34-37]). Photo: Stefanos Michael.

Phylum Chordata Haeckel, 1874

Class Actinopteri Cope, 1871

Order Carangiformes Jordan, 1923

Family Carangidae Rafinesque, 1815

Genus Seriola Cuvier, 1816

Seriola fasciata (Bloch, 1793)

(Figure 2A) 
Material examined. One specimen of around $25 \mathrm{~cm}$ TL was photographed from Larnaca, Cyprus, Levantine Sea (34.8999 N, 33.6692 E), on 14 March 2021. It was fished at $10 \mathrm{~m}$ depth from a mixed-bottom sea floor by Giannos Pambakas.

Remarks. The specimen was identified according to the identification key by Fischer et al. [38]. This is a thermophilic Atlantic species that has colonized the Mediterranean in the last three decades and is expanding its distribution northward along the eastern Atlantic coast as well [39]. The first record of S. fasciata in the Mediterranean Sea dates back to 1989 [40], but, by the end of the 1990s, the species was already widespread around Sicily [41,42]. Currently, S. fasciata has also been reported in Libya [43], Malta [44], Greece [45], Turkey [46], Syria [47], Lebanon [48], Israel [49], and Egypt [50]; however, the report by Quignard and Tomasini [51] for Mediterranean France was considered to be doubtful by Geraci et al. [52]. The present record represents the first occurrence of the species in Cypriot waters. At present, no impact on native species populations has been detected, even though a possible impact from competition with fish species with a similar ecological niche might be forecast, as suggested for other demersal predators $[53,54]$.

Order Gobiiformes Günther, 1880

Family Gobiidae Cuvier, 1816

Genus Oxyurichthys Bleeker, 1857

Oxyurichthys petersii (Klunzinger, 1871)

(Figures 2B and S1-S3)

Material examined. One specimen was photographed in Crete, Greece, Aegean Sea $(35.4895 \mathrm{~N}, 24.1514 \mathrm{E})$, on 18 October 2020. The specimen was found at $2 \mathrm{~m}$ depth, during recreational fishing on a muddy bottom by Giannis Kakavelakis. One specimen was photographed in the Amvrakikos Gulf, Greece, Ionian Sea (38.9365 N, 20.7850 E), on 15 November 2020. The specimen was found at $10 \mathrm{~m}$ depth, in gill nets set on a muddy bottom, by Ioannis Charalampitzas. One specimen was photographed in Paralimni, Cyprus, Levantine Sea (35.0589 N, 34.0189 E), on 1 December 2020. The specimen was found at $5 \mathrm{~m}$ depth, during recreational fishing, by Kipros Kiriakidis. One specimen was photographed in the Amvrakikos Gulf, Greece, Ionian Sea (38.9342 N, 20.7911 E), on 20 September 2021. The specimen came from an unknown depth, and was found in gill nets set on a muddy bottom by Dimitris Tsalikidis.

Remarks. Oxyurichthys petersii is a Lessepsian species first reported in the Mediterranean Sea off Israel in 1982 [55] and is nowadays very common throughout the Levantine Sea [56]. According to Ben Rais Lasram et al. [57], this is a strictly tropical species for which a small colonization success can be forecast for the western Mediterranean Sea; accordingly, until recently, the westernmost records referred to the eastern Aegean Sea [58,59]. The specimen reported for Paralimni represents the first occurrence for Cyprus [60], while the individuals sampled in Crete and in the Amvrakikos Gulf show a significant expansion westward; the latter also represent the first record of the species in the Ionian Sea, where it seems to be established. According to professional fishermen from the Amvrakikos Gulf, a scanty but regular occurrence of $O$. petersii in coastal fishery catches started in 2020, and the species is usually caught in the summer (Dimitris Tsalikidis, pers. comm.). Although this species has been found in the Eastern Mediterranean since the early 1980s and is a relatively regular catch of bottom-trawlers, it did not seem to experience the dramatic increase reported for other Lessepsian species [8], thus suggesting a very limited impact on native assemblages. 


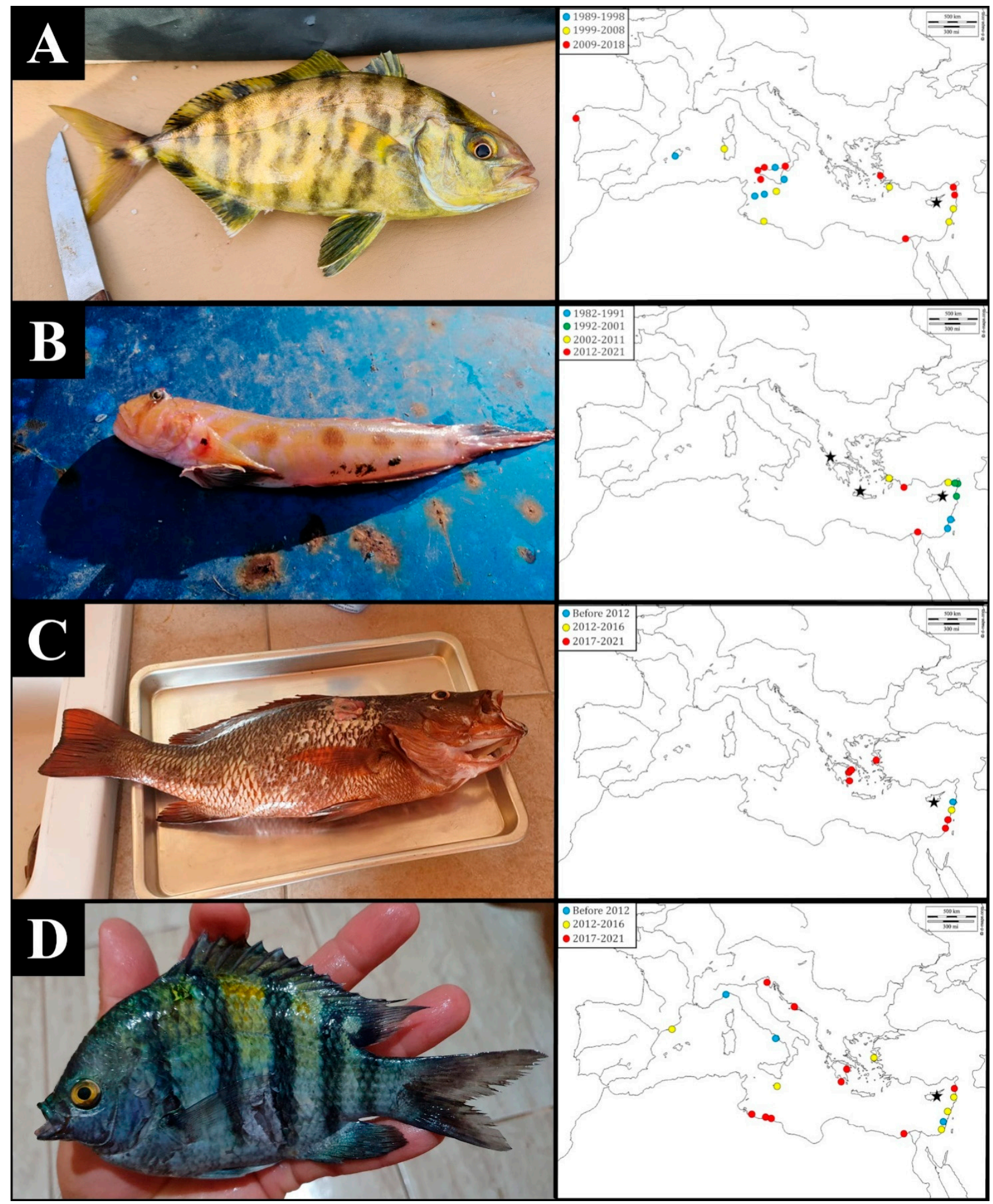

Figure 2. NIS and neo-native species newly recorded from Greece and Cyprus (part 2). New distributional data are marked by a black star. (A) Seriola fasciata from Larnaca (Cyprus) and known records in the Mediterranean Sea (after [39,52]). Photo: Giannos Pambakas. (B) Oxyurichthys petersii from the Amvrakikos Gulf (Greece) and known records in the Mediterranean Sea (after [6,55,58,59,61-63]. Photo: Ioannis Charalampitzas. (C) Lutjanus argentimaculatus from Limassol (Cyprus) and known records in the Mediterranean Sea (after [12]). Photo: Michalis Kanaris. (D) Abudefduf sp. (cf. saxatilis/vaigiensis/troschelii) from Liopetri (Cyprus) and known records in the Mediterranean Sea (after [64,65]). Photo: Valantis Christofi. 
Order Lutjaniformes Bleeker, 1873

Family Lutjanidae Gill, 1861

Genus Lutjanus Bloch, 1790

Lutjanus argentimaculatus (Forsskål, 1775)

(Figure 2C)

Material examined. One specimen was photographed in Limassol, Cyprus, Levantine Sea $(34.6646 \mathrm{~N}, 33.0405 \mathrm{E})$. The specimen was speared on a rocky bottom at $2 \mathrm{~m}$ depth by Michalis Kanaris; the length was not reported, and the weight was approximately $2500 \mathrm{~g}$.

Remarks. After the first Mediterranean record by Mouneimné [66], this Lessepsian species apparently disappeared from the Mediterranean Sea, being reported with several specimens only in the 2010s, thereby suggesting the presence of a reproductive population [12,67-69]. Currently, the species has been reported in Israel, Lebanon, Syria, Turkey, and Greece, with the westernmost records in the southwestern Aegean Sea. The present record represents the first occurrence of this species in Cyprus. As this species is a large demersal predator, occupying an ecological niche similar to that of native groupers, the impact on native assemblages can be forecast in case of the establishment of an abundant population, as suggested for other species with a similar ecology [11]. For this reason, even if L. argentimaculatus is known in the Mediterranean Sea from only a few records, its spread and establishment need to be carefully monitored.

Order Ovalentaria Smith \& Near, 2012 incertae sedis

Family Pomacentridae Bonaparte, 1831

Genus Abudefduf Forsskål, 1775

Abudefduf cf. saxatilis/vaigiensis/troschelii sensu Dragičević et al. [70]

(Figures 2D, S4 and S5)

Material examined. One specimen (sampled and deposited frozen at the MER collections) was reported at Liopetri, Cyprus, Levantine Sea (34.9690 N, 33.9049 E), on 21 May 2021. The specimen was found at $4 \mathrm{~m}$ depth, speared on a sandy bottom by Valantis Christofi, and was $20 \mathrm{~cm}$ TL. Two specimens were photographed in Larnaca, Cyprus, Levantine Sea (34.9272 N, 33.6468 E), and were observed at $1 \mathrm{~m}$ depth, on a rocky bottom, by George Georgiou. One specimen was photographed by Dimitris Vattis in Dhekelia, Cyprus, Levantine Sea (34.9784 N, $33.7261 \mathrm{E})$, at $4 \mathrm{~m}$ depth, on a rocky bottom.

Remarks. Despite the high number of records reported after the first sighting by Tardent [71], the identity and distribution of Abudefduf species in the Mediterranean Sea are still unclear. The majority of records are based on underwater photographs, while molecular confirmation of the identity of the specimens was provided for only four records [72-75], which confirmed that both $A$. vaigiensis and $A$. saxatilis occur in the Mediterranean Sea. By examining photographs from the native range of the two species, Dragičević et al. [70] highlighted a strong overlap in phenotypes between the two taxa, which suggests that morphological characteristics traditionally employed for their identification are not reliable. Moreover, a third species, $A$. troschelii, has never been reported for the Mediterranean Sea, but it is impossible to discriminate it from $A$. saxatilis and $A$. vaigiensis based on underwater photographs; for this reason, Dragičević et al. [70] referred to those records of A. saxatilis and $A$. vaigiensis that were without molecular confirmation as Abudefduf cf. saxatilis/vaigiensis/troschelii; we are herein following their advice for the specimens recently reported for Cyprus. Although $A$. vaigiensis does, in fact, occur in the Red Sea, the scanty records from the Eastern Mediterranean Sea and their contemporary appearance in several distant Mediterranean localities strongly suggest that, in this case, their introduction did not follow the typical expansion pattern through the Suez Canal and along the coasts of the Eastern Mediterranean but was instead due to aquarium releases, as postulated for A. saxatilis. Despite the high number of records (around 50, including those published here), 
the occurrence of reproductive populations of Abudefduf cf. saxatilis/vaigiensis/troschelii is still unclear; the majority of records are possibly due to repeated introductions of this very popular aquarium fish. However, repeated and frequent records of Abudefduf cf. saxatilis/vaigiensis/troschelii off the coasts of Israel [73] and Malta [74], as well as the presence of juveniles in Libya [75], suggest that, at least in these areas, the species had some establishment success. Although the presence of several records along the Southern Cyprus coastline in 2021 might suggest a similar scenario and the occurrence of a local reproductive population, further research is needed to clarify this point. Moreover, it is possible that the introduced Abudefduf cf. saxatilis/vaigiensis/troschelii occurring in the Mediterranean might belong to hybrid populations of the two species, a phenomenon observed elsewhere in the genus Abudefduf [70]. At present, the scarcity of molecular data, and the fact that they only refer to mitochondrial markers, does not allow to confirm or deny this hypothesis, but a further sampling effort, and the use of nuclear markers, would be of great interest to understand the identity and the evolutionary processes concerning these NIS in the Mediterranean Sea. While, until now, all non-indigenous Pomacentridae reported in the Mediterranean Sea were considered as casual occurrences [75], the current increase in records of Abudefduf cf. saxatilis/vaigiensis/troschelii in the last ten years (see Figure 2D) might suggest that this species is increasing in number and spreading across the Eastern part of the basin. Even though there are no reliable data suggesting an ecological impact of non-indigenous Pomacentridae in the Mediterranean Sea and even in other areas of the world [76], its competition with native species and in particular with the native Chromis chromis (Linnaeus, 1758) cannot be excluded, which is particularly worrying, as the latter has a key ecological role in Mediterranean ecosystems [77].

\section{Conclusions}

All records included here constitute significant updates of the species' known occurrence range. However, they can be separated into two main categories, namely, records that fill a gap in the distribution of a species, where their novelty is presumably due to a missed detection, and records suggesting an actual range expansion.

The Lessepsian L. argentimaculatus and O. petersii and the tropical Atlantic S. fasciata were already known, respectively, in the Aegean Sea [12,59] and in almost the entire Mediterranean Sea [52]; thus, their occurrence in Cyprus was somehow predictable, although these species were not officially reported until now. For L.argentimaculatus, the extremely low densities at which this large predator seems to occur explains why all Mediterranean records are due to casual reports by citizen scientists and why the species is virtually undetected by fishery studies [12]. In the case of $S$. fasciata, the vast majority of records refer to juveniles, which are easier to tell apart from the native and widespread Seriola dumerili (Risso, 1810) than the adults [52]. Therefore, it is not unlikely that this species is much more widespread than current data suggest, but that after losing the juvenile livery, this species is systematically misidentified in the Mediterranean Sea. Similarly, the population of B. luctuosum occurring in Messolonghi harbor is most likely not a recent introduction but has presumably been overlooked due to a scarcity of studies focusing on port assemblages along the Greek coastline [33]. It is likely that further studies and a higher sampling effort will highlight a wider distribution for this species in the eastern Ionian Sea and, in particular, in ports and enclosed environments, as already observed along the Italian and Spanish coastlines.

On the other hand, in the case of the records of O. petersii off Crete and in the Amvrakikos Gulf, as well as the record of S. marmoratus off Cyprus, we are most likely in the presence of an actual process of westward expansion. The case of $O$. petersii is particularly interesting, as this species is considered a strictly tropical species with a low likelihood of showing significant expansion toward the westernmost part of the basin [55], thus ranking low in a recent risk screening for Turkish waters [78]. However, the presence of this species with an established population in the eastern Ionian Sea suggests instead that a range 
expansion westward is currently happening, and the appearance of this species in other areas of the Ionian Sea and the Aegean Sea should be carefully monitored.

In conclusion, the data reported in this paper highlight the importance of the contribution by citizen scientists to knowledge of the Mediterranean assemblages, particularly in reference to the so-called rare species, whether non-indigenous or native. Moreover, the majority of NIS occur at very low densities in the first stages of their invasion process; thus, they are usually overlooked by traditional monitoring techniques [7]. The westward expansion of the highly invasive lionfish P. miles, for instance, has also been carefully monitored thanks to reports by citizen scientists, who were even responsible for the first records in new biogeographical sectors $[79,80]$; moreover, a thorough overview of its distribution, allowing researchers to build habitat suitability and expansion models, was only possible by using data gathered through citizen science [81]. Finally, lag times between the first record of a species and the development of invasive populations are relatively frequent and might represent useful temporal windows for the establishment of prevention and management practices [82]. For these reasons, serendipitous observations by fishermen, divers, and, more generally, nature enthusiasts might represent a precious source of data by which to track NIS at the edge of their range and follow their expansion $[10,11,15]$.

Supplementary Materials: The following are available online at https:/ / www.mdpi.com/article/ 10.3390/jmse10020256/s1; Figure S1: Oxyurichthys petersii from Crete, Greece, Aegean Sea. Figure S2: Oxyurichthys petersii from Paralimni, Cyprus, Levantine Sea. Figure S3: Oxyurichthys petersii from Amvrakikos Gulf, Greece, Ionian Sea. Figure S4: Abudefduf cf. saxatilis/vaigiensis/troschelii from Larnaca, Cyprus, Levantine Sea. Figure S5: Abudefduf cf. saxatilis/vaigiensis/troschelii from Dhekelia, Cyprus, Levantine Sea.

Author Contributions: Conceptualization, J.L. and F.C.; methodology, J.L. and F.C.; validation, J.L., F.T. and F.C.; investigation, V.M., N.D., I.G., A.K. and P.K.; resources, N.D., I.G. and P.K.; data curation, V.M. and A.K.; writing—original draft preparation, J.L.; writing—review and editing, V.M., N.D., I.G., A.K., P.K., F.T. and F.C.; supervision, F.C. All authors have read and agreed to the published version of the manuscript.

Funding: This research received no external funding.

Institutional Review Board Statement: Ethical review and approval were waived for this study as it did not include direct sampling.

Informed Consent Statement: Not applicable.

Data Availability Statement: Not applicable.

Acknowledgments: We are grateful to Ioannis Charalampitzas, Valantis Christofi, George Georgiou, Michalis Kanaris, Kipros Kiriakidis, Stefanos Michael, Giannos Pambakas, Dimitris Tsalikidis, and Dimitris Vattis for sharing data and, eventually, samples.

Conflicts of Interest: The authors declare no conflict of interest.

\section{References}

1. Vilà, M.; Basnou, C.; Pyšek, P.; Joseffson, M.; Genovesi, P.; Gollasch, S.; Nentwig, W.; Olenin, S.; Roques, A.; Roy, D.; et al. How well do we understand the impacts of alien species on ecosystem services? A pan-European, cross-taxa assessment. Front. Ecol. Environ. 2010, 8, 135-144. [CrossRef]

2. Nentwig, W.; Bacher, S.; Pyšek, P.; Vilà, M.; Kumschick, S. The generic impact scoring system (GISS): A standardized tool to quantify the impacts of alien species. Environ. Monit. Assess. 2016, 188, 315. [CrossRef]

3. Boon, P.J.; Clarke, S.A.; Copp, G.H. Alien species and the EU Water Framework Directive: A comparative assessment of European approaches. Biol. Invasions 2020, 22, 1497-1512. [CrossRef]

4. Tsiamis, K.; Azzurro, E.; Bariche, M.; Çinar, M.E.; Crocetta, F.; De Clerck, O.; Galil, B.; Gómez, F.; Hoffman, R.; Jensen, K.R.; et al. Prioritizing marine invasive alien species in the European Union through horizon scanning. Aquat. Conserv. 2020, $30,794-845$. [CrossRef]

5. Kleitou, P.; Crocetta, F.; Giakoumi, S.; Giovos, I.; Hall-Spencer, J.M.; Kalogirou, S.; Kletou, D.; Mutopoulos, D.K.; Rees, S. Fishery reforms for the management of non-indigenous species. J. Environ. Manag. 2021, 280, 111690. [CrossRef] [PubMed] 
6. Katsanevakis, S.; Poursanidis, D.; Hoffman, R.; Rizgalla, J.; Rothman, S.B.S.; Levitt-Barmats, Y.; Hadjioannou, L.; Trkov, D.; Garmendia, J.M.; Rizzo, M.; et al. Unpublished Mediterranean records of marine alien and cryptogenic species. Bioinvasions Rec. 2020, 9, 165-182. [CrossRef]

7. Kleitou, P.; Giovos, I.; Wolf, W.; Crocetta, F. On the importance of citizen-science: The first record of Goniobranchus obsoletus (Rüppell and Leuckart, 1830) from Cyprus (Mollusca: Gastropoda: Nudibranchia). Bioinvasions Rec. 2019, 8, 252-257. [CrossRef]

8. Arndt, E.; Marchetti, M.P.; Schembri, P.J. Ecological impact of alien marine fishes: Insights from freshwater systems based on a comparative review. Hydrobiologia 2018, 817, 457-474. [CrossRef]

9. Crocetta, F.; Gofas, S.; Salas, C.; Tringali, L.P.; Zenetos, A. Local ecological knowledge versus published literature: A review of non-indigenous Mollusca in Greek marine waters. Aquat. Invasions 2017, 12, 415-434. [CrossRef]

10. Tiralongo, F.; Crocetta, F.; Riginella, E.; Lillo, A.O.; Tondo, E.; Macali, A.; Mancini, E.; Russo, F.; Coco, S.; Paolillo, G.; et al. Snapshot of rare, exotic and overlooked fish species in Italian seas: A citizen science survey. J. Sea Res. 2020, 164, 101930. [CrossRef]

11. Langeneck, J.; Marcelli, M.; Bariche, M.; Azzurro, E. Social networks allow early detection of non indigenous species: First record of the red drum Sciaenops ocellatus (Actinopterygii: Perciformes: Sciaenidae) in Italian waters. Acta Adriat. 2017, 58, 365-370. [CrossRef]

12. Tiralongo, F.; Giovos, I.; Doumpas, N.; Langeneck, J.; Kleitou, P.; Crocetta, F. Is the mangrove red snapper Lutjanus argentimaculatus (Forsskål, 1775) established in the eastern Mediterranean Sea? First records from Greece through a citizen science project. Bioinvasions Rec. 2019, 8, 911-916. [CrossRef]

13. Kleitou, P.; Rees, S.; Cecconi, F.; Kletou, D.; Savva, I.; Cai, L.L.; Hall-Spencer, J.M. Regular monitoring and targeted removals can control lionfish in Mediterranean Marine Protected Areas. Aquat. Conserv. 2021, 31, 2870-2882. [CrossRef]

14. Kleitou, P.; Hall-Spencer, J.M.; Savva, I.; Kletou, D.; Hadjistylli, M.; Azzurro, E.; Katsanevakis, S.; Antoniou, C.; Hadjioannou, L.; Chartosia, N.; et al. The case of lionfish (Pterois miles) in the Mediterranean Sea demonstrates limitations in EU legislation to address marine biological invasions. J. Mar. Sci. Eng. 2021, 9, 325. [CrossRef]

15. Giovos, I.; Kleitou, P.; Poursanidis, D.; Batjakas, I.; Bernardi, G.; Crocetta, F.; Doumpas, N.; Kalogirou, S.; Kampouris, T.; Keramidas, I.; et al. Citizen-science for monitoring marine invasions and stimulating public engagement-A case project from the eastern Mediterranean. Biol. Invasions 2019, 21, 3707-3721. [CrossRef]

16. Giovos, I.; Tiralongo, F.; Langeneck, J.; Kaminas, A.; Kleitou, P.; Crocetta, F.; Doumpas, N. First record of the Atlantic spadefish Chaetodipterus faber (Broussonet, 1782) in the Mediterranean Sea: Is it a new aquarium release? Bioinvasions Rec. 2020, 9, 89-95. [CrossRef]

17. Minasidis, V.; Doumpas, N.; Kleitou, P.; Naasan Aga Spyridopoulou, R.; Papadamakis, P.; Giovos, I. Additional records of tripletail Lobotes surinamensis (Bloch,1790) from the Eastern Mediterranean. Thalassas 2020, 36, 557-563. [CrossRef]

18. Naasan Aga Spyridopoulou, R.; Langeneck, J.; Bouziotis, D.; Giovos, I.; Kleitou, P.; Kalogirou, S. Filling the gap of data-limited fish species in the Eastern Mediterranean Sea. J. Mar. Sci. Eng. 2020, 8, 107. [CrossRef]

19. Knight-Jones, P.; Knight-Jones, W.; Ergen, Z. Sabelliform polychaetes, mostly from Turkey's Aegean coast. J. Nat. Hist. 1991, 25, 837-858.

20. Langeneck, J.; Lezzi, M.; Del Pasqua, M.; Musco, L.; Gambi, M.C.; Castelli, A.; Giangrande, A. Non-indigenous polychaetes along the coasts of Italy: A critical review. Medit. Mar. Sci. 2020, 20, 238-275. [CrossRef]

21. El Haddad, M.; Capaccioni Azzati, R.; García-Carrascosa, A.M. Branchiomma luctuosum (Polychaeta: Sabellidae): A non indigenous species at Valencia port (western Mediterranean Sea, Spain). Mar. Biodivers. Rec. 2008, 1, e6. [CrossRef]

22. Fernández-Romero, A.; Navarro-Barranco, C.; Ros, M.; Arias, A.; Moreira, J.; Guerra-Garcia, J.M. To the Mediterranean and beyond: An integrative approach to evaluate the spreading of Branchiomma luctuosum (Annelida: Sabellidae). Estuar. Coast. Shelf Sci. 2021, 254, 107357. [CrossRef]

23. Tanduo, V.; Golemaj, A.; Crocetta, F. Citizen-science detects the arrival and establishment of Branchiomma luctuosum (Grube, 1870) (Annelida: Polychaeta: Sabellidae) in Albania. Biodivers. Data J. 2020, 8, e54790. [CrossRef] [PubMed]

24. Arvanitidis, C. Polychaete fauna of the Aegean Sea: Inventory and new information. Bull. Mar. Sci 2000, 66, 73-96.

25. Zenetos, A.; Vassilopoulou, V.; Salomidi, M.; Poursanidis, D. Additions to the marine alien fauna of Greek waters (2007 update). Mar. Biodivers. Rec. 2008, 1, e91. [CrossRef]

26. Çinar, M.E. Polychaetes from the coast of northern Cyprus (eastern Mediterranean Sea), with two new records for the Mediterranean Sea. Cah. Biol. Mar. 2005, 46, 143-159.

27. Çinar, M.E.; Bilecenoğlu, M.; Öztürk, B.; Can, A. New records of alien species on the Levantine coast of Turkey. Aquat. Invasions 2006, 1, 84-90. [CrossRef]

28. Crocetta, F.; Al Mabruk, S.A.A.; Azzurro, E.; Bakiu, R.; Bariche, M.; Batjakas, I.E.; Bejaoui, T.; BenSouissi, J.; Cauchi, J.; Corsini-Foka, M.; et al. New alien Mediterranean biodiversity records (November2021). Medit. Mar. Sci. 2021, 22, 724-746.

29. Mabrouki, Y.; Crocetta, F.; Taybi, A.F. First record of Branchiomma luctuosum (Grube, 1870) (Annelida: Polychaeta: Sabellidae) in Morocco. Thalassas 2021, 37, 717-720. [CrossRef]

30. Tempesti, J.; Langeneck, J.; Maltagliati, F.; Castelli, A. Macrobenthic fouling assemblages and NIS success in a Mediterranean port: The role of use destination. Mar. Pollut. Bull. 2020, 150, 110768. [CrossRef] 
31. Tamburini, M.; Keppel, E.; Marchini, A.; Repetto, M.F.; Ruiz, G.; Ferrario, J.; Occhipinti-Ambrogi, A. Monitoring non-indigenous species in port habitats: First application of a standardized North American protocol in the Mediterranean Sea. Front. Mar. Sci. 2021, 8, 904. [CrossRef]

32. Tempesti, J.; Mangano, M.C.; Langeneck, J.; Maltagliati, F.; Lardicci, C.; Castelli, A. Non-indigenous species in Mediterranean ports: A knowledge baseline. Mar. Environ. Res. 2020, 161, 105056. [CrossRef]

33. Mastrototaro, F.; Chimienti, G.; Matarrese, A.; Gambi, M.C.; Giangrande, A. Growth and population dynamics of the nonindigenous species Branchiomma luctuosum Grube (Annelida; Sabellidae) in the Ionian Sea (Mediterranean Sea). Mar. Ecol. 2015, 36, 517-529. [CrossRef]

34. Rothman, S.B.S.; Shlagman, A.; Galil, B.S. Saron marmoratus, an Indo-Pacific marble shrimp (Hippolytidae: Decapoda: Crustacea) in the Mediterranean Sea. Mar. Biodivers. Rec. 2013, 6, e129. [CrossRef]

35. Zenetos, A.; Akel, E.H.K.; Apostolidis, C.; Bilecenoglu, M.; Bitar, G.; Buchet, V.; Chalari, N.; Corsini-Foka, M.; Crocetta, F.; Dogrammatzi, A.; et al. New Mediterranean biodiversity records (April 2015). Medit. Mar. Sci. 2015, 16, 266-284. [CrossRef]

36. Ammar, I.; Raya, R. First record of marbled shrimp Saron marmoratus (Olivier, 1811) from Syrian marine waters. Int. J. Zool. 2019, 4, 8-10.

37. Ergüden, D.; Uygar, N.; Ayan, O.; Gürlek, M.; Uyan, A.; Karan, S.; Doğdu, S.A.; Turan, C. First record marbled shrimp Saron marmoratus (Olivier, 1811) from Turkish marine waters. Nat. Eng. Sci. 2018, 3, 141-146. [CrossRef]

38. Fischer, W.; Bianchi, G.; Scott, W.B. FAO Species Identification Sheets for Fishery Purposes. Eastern Central Atlantic. Fishing Areas 34, 47; Canada Funds-in-Trust: Ottawa, ON, Canada, 1981; Volume 1, 326p.

39. Bañón, R.; Mucientes, G. First record of Seriola fasciata (Carangidae) from Galician waters (NW Spain). A new northernmost occurrence in the NE Atlantic. Cybium 2009, 33, 247-248.

40. Massuti, E.; Stefanescu, C. First record of Seriola fasciata (Bloch, 1793) (Osteichthyes: Carangidae) in the Mediterranean. J. Fish Biol. 1993, 42, 143-144. [CrossRef]

41. Andaloro, F.; Falautano, M.; Sinopoli, M.; Passarelli, F.M.; Pipitone, C.; Addis, P.; Cau, A.; Castriota, L. The lesser amberjack Seriola fasciata (Perciformes: Carangidae) in the Mediterranean: A recent colonist? Cybium 2005, 29, 141-145.

42. Tiralongo, F.; Tibullo, D.; Messina, G.; Lombardo, B.M. New records of two carangid species from the south-east coast of Sicily (Ionian Sea) and considerations about their presence and abundance. Acta Adriat. 2018, 59, 225-230. [CrossRef]

43. Shakman, E.A.; Abdalha, A.B.; Thala, F.; Alfaturi, A.; Bariche, M. First records of seven marine organisms of different origins from Libya (Mediterranean Sea). Bioinvasions Rec. 2017, 6, 377-382. [CrossRef]

44. Deidun, A.; Castriota, L.; Arrigo, S. A tale of two Atlantic fish migrants: Records of the lesser amberjack Seriola fasciata and the African hind Cephalopholis taeniops from the Maltese Islands. J. Black Sea Medit. Environ. 2011, 17, 223-233.

45. Corsini, M.; Margies, P.; Kondilatos, G.; Economidis, P.E. Three new exotic fish records from the SE Aegean Greek waters. Sci. Mar. 2006, 70, 319-323. [CrossRef]

46. Kapiris, K.; Apostolidis, C.; Baldacconi, R.; Başusta, N.; Bilecenoglu, M.; Bitar, G.; Bobori, D.C.; Boyaci, Y.Ö.; Dimitriadis, C.; Djurović, M.; et al. New Mediterranean biodiversity records (April 2014). Medit. Mar. Sci. 2014, 15, 198-212. [CrossRef]

47. Jawad, L.; Mtawej, A.; Ibrahim, A.; Hassan, M. First record of the lesser amberjack Seriola fasciata (Teleostei: Carangidae) in Syrian coasts. Cah. Biol. Mar. 2015, 56, 81-84.

48. Crocetta, F.; Agius, D.; Balistreri, P.; Bariche, M.; Bayhan, Y.; Çakir, M.; Ciriaco, S.; Corsini-Foka, M.; Deidun, A.; El Zrelli, R.; et al. New Mediterranean biodiversity records (October 2015). Medit. Mar. Sci. 2015, 16, 682-702. [CrossRef]

49. Sonin, O.; Salameh, P.; Golani, D. First record of the lesser amberjack, Seriola fasciata (Actinopterygii: Perciformes: Carangidae) in the Levant. Acta Ichthyol. Piscat. 2009, 39, 71-73. [CrossRef]

50. Lipej, L.; Acevedo, I.; Akel, E.; Anastasopoulou, A.; Angelidis, A.; Azzurro, E.; Castriota, L.; Çelik, M.; Cilenti, L.; Crocetta, F.; et al. New Mediterranean biodiversity records (March 2017). Medit. Mar. Sci. 2017, 18, 179-201. [CrossRef]

51. Quignard, J.P.; Tomasini, J.A. Mediterranean fish biodiversity. Biol. Mar. Medit. 2000, 7, 1-66.

52. Geraci, M.L.; Falsone, F.; Scannella, D.; Vitale, S. An additional record of the non-indigenous species (NIS) Seriola fasciata from the southern coast of Sicily (Central Mediterranean Sea). Acta Adriat. 2020, 61, 223-230. [CrossRef]

53. Valls, M.; Grau, A.M.; Massutí, E.; Tobaruela, A.; Riera, F. First record of Seriola rivoliana (Osteichthyes: Carangidae) In the western Mediterranean. Mar. Biodiv. Rec. 2011, 4, e91. [CrossRef]

54. Peña Rivas, L.; Langeneck, J.; Azzurro, E. First record of Dentex canariensis Steindachner, 1881 (Perciformes: Sparidae) in the Mediterranean Sea. J. Appl. Ichthyol. 2018, 34, 669-671. [CrossRef]

55. Ben-Tuvia, A. An Indo-Pacific goby Oxyurichthys papuensis in the Mediterranean. Isr. J. Zool. 1983, 32, 37-43.

56. Golani, D.; Orsi-Relini, L.; Massuti, E.; Quignard, J.P. CIESM Atlas of Exotic Species in the Mediterranean, Volume 1, Fishes; CIESM Publishers: Monaco-Ville, Monaco; p. 256.

57. Ben Rais Lasram, F.; Tomasini, J.A.; Guilhaumon, F.; Romdhane, M.S.; Do Chi, T.; Mouillot, D. Ecological correlates of dispersal success of Lessepsian species. Mar. Ecol. Prog. Ser. 2008, 363, 273-286. [CrossRef]

58. Akyol, O.; Ünal, V.; Ceyhan, T. Occurrence of two Lessepsian migrant fish, Oxyurichthys petersii (Gobiidae) and Upeneus pori (Mullidae) from the Aegean Sea. Cybium 2006, 30, 389-390.

59. Karachle, P.K.; Angelidis, A.; Apostolopoulos, D.; Ayas, D.; Ballesteros, M.; Bonnici, C.; Brodersen, M.M.; Castriota, L.; Chalari, N.; Cottalorda, J.M.; et al. New Mediterranean biodiversity records (March 2016). Medit. Mar. Sci. 2016, 17, 230-252. [CrossRef]

60. Iglésias, S.P.; Frotté, L. Alien marine fishes in Cyprus: Update and new records. Aquat. Invasions 2015, 10, 425-438. [CrossRef] 
61. Pezold, F.L.; Larson, H.K. A revision of the fish genus Oxyurichthys (Gobioidei: Gobiidae) with descriptions of four new species. Zootaxa 2015, 3988, 1-95. [CrossRef]

62. Haroun, E.S.; Akel, K.; Karachle, P.K. The marine ichthyofauna of Egypt. Egypt. J. Aquat. Biol. Fish. 2017, 21, 81-116.

63. Ali, M.F. An updated checklist of the marine fishes from Syria with emphasis on alien species. Medit. Mar. Sci. 2018, 19, 388-393. [CrossRef]

64. Al Mabruk, S.A.A.; Abdulghani, A.; Nour, O.M.; Adel, M.; Crocetta, F.; Doumpas, N.; Kleitou, P.; Tiralongo, F. The role of social media in compensating for the lack of field studies: Five new fish species for Mediterranean Egypt. J. Fish Biol. 2021, 99, 673-678. [CrossRef] [PubMed]

65. Bitar, G. Occurrence of Abudefduf spp. (Pisces: Pomacentridae) in the Lebanese coastal waters (eastern Mediterranean)Morphological traits and visual evidence. Medit. Mar. Sci. 2021, 22, 715-723. [CrossRef]

66. Mouneimné, N. Poissons nouveaux pour les côtes libanaises (Méditerranée orientale). Cybium 1979, 3, $105-110$.

67. Dailianis, T.; Akyol, O.; Babali, N.; Bariche, M.; Crocetta, F.; Gerovasileiou, V.; Ghanem, R.; Gökoğlu, M.; Hasiotis, T.; Izquierdo-Muñoz, A.; et al. New Mediterranean biodiversity records (July 2016). Medit. Mar. Sci. 2016, 17, 608-626. [CrossRef]

68. Akyol, O. The first record of a mangrove red snapper, Lutjanus argentimaculatus (Actinopterygii: Perciformes: Lutjanidae), from the Aegean Sea (Gulf of Izmir, Turkey). Acta Ichthyol. Piscat. 2019, 49, 209-211. [CrossRef]

69. Sonin, O.; Edelist, D.; Golani, D. The occurrence of the Lessepsian migrant Lutjanus argentimaculatus in the Mediterranean (Actinopterygii: Perciformes: Lutjanidae), first record from the coast of Israel. Acta Adriat. 2019, 60, 99-102. [CrossRef]

70. Dragičević, B.; Fricke, R.; Ben Souissi, J.; Ugarković, P.; Dulčić, J.; Azzurro, E. On the occurrence of the genus Abudefduf spp. (Pisces: Pomacentridae) in the Mediterranean Sea: A critical review with new records. Bioinvasions Rec. 2021, 10, 188-199. [CrossRef]

71. Tardent, P. Capture d'un Abudefduf saxatilis vaigiensis Q. und G. (Pisces, Pomacentridae) dans le Golfe de Naples. Rev. Suisse Zool. 1959, 66, 347-351. [CrossRef]

72. Bariche, M.; Torres, M.; Smith, C.; Sayar, N.; Azzurro, E.; Baker, R.; Bernardi, G. Red Sea fishes in the Mediterranean Sea: A preliminary investigation of a biological invasion using DNA barcoding. J. Biogeogr. 2015, 42, 2363-2373. [CrossRef]

73. Tsadok, R.; Rubin-Blum, M.; Shemesh, E.; Tchernov, D. On the occurrence and identification of Abudefduf saxatilis (Linnaeus, 1758) in the easternmost Mediterranean Sea. Aquat. Invasions 2015, 10, 101-105. [CrossRef]

74. Vella, A.; AgiusDarmanin, S.; Vella, N. The first records of Indo-Pacific sergeant Abudefduf vaigiensis (Quoy and Gaimard, 1825) and further notes on the occurrence of sergeant major A. saxatilis (Linnaeus, 1758) in Malta: Expanding populations of an invasive genus in the Mediterranean Sea. J. Black Sea Medit. Environ. 2016, 22, 1-15.

75. Osca, D.; Tanduo, V.; Tiralongo, F.; Giovos, I.; Almabruk, S.A.A.; Crocetta, F.; Rizgalla, J. The Indo-Pacific Sergeant Abudefduf vaigiensis (Quoy \& Gaimard, 1825) (Perciformes: Pomacentridae) in Libya, South-Central Mediterranean Sea. J. Mar. Sci. Eng. 2020, 8, 14 .

76. Anderson, A.B.; Pereira da Silva, J.; Sorvilo, R.; Francini, C.L.B.; Floeter, S.R.; Barreiros, J.P. Population expansion of the invasive Pomacentridae Chromis limbata (Valenciennes, 1833) in southern Brazilian coast: Long-term monitoring, fundamental niche availability and new records. J. Fish Biol. 2020, 97, 362-373. [CrossRef] [PubMed]

77. Pinnegar, J.K. Why the damselfish Chromis chromis is a key species in the Mediterranean rocky littoral - A quantitative perspective. J. Fish Biol. 2018, 92, 851-872. [CrossRef] [PubMed]

78. Bilge, G.; Filiz, H.; Yapici, S.; Tarkan, A.S.; Vilizzi, L. A risk screening study on the potential invasiveness of Lessepsian fishes in the south-western coasts of Anatolia. Acta Ichthyol. Piscat. 2019, 49, 23-31. [CrossRef]

79. Azzurro, E.; Stancanelli, B.; Di Martino, V.; Bariche, M. Range expansion of the common lionfish Pterois miles (Bennett, 1828) in the Mediterranean Sea: An unwanted new guest for Italian waters. Bioinvasions Rec. 2017, 6, 95-98. [CrossRef]

80. Dragičević, B.; Ugarković, P.; Krželj, M.; Zurub, D.; Dulčić, J. New record of Pterois cf. miles (Actinopterygii: Scorpaeniformes: Scorpaenidae) from the eastern middle Adriatic Sea (Croatian waters): Northward expansion. Acta Ichthyolog. Piscat. 2021, 51, 379-383.

81. Dimitriadis, C.; Galanidi, M.; Zenetos, A.; Corsini-Foka, M.; Giovos, I.; Karachle, P.K.; Fournari-Konstantinidoy, I.; Kytinou, E.; Issaris, Y.; Azzurro, E.; et al. Updating the occurrences of Pterois miles in the Mediterranean Sea, with considerations on thermal boundaries and future range expansion. Medit. Mar. Sci. 2020, 21, 62-69. [CrossRef]

82. Coutts, S.R.; Helmstedt, K.J.; Bennett, J.R. Invasion lags: The stories we tell ourselves and our inability to infer process frompattern. Divers. Distrib. 2018, 24, 244-251. [CrossRef] 